\title{
Nação e (ou) Socialismo: Mariátegui, Haya de la Torre e a INTERNACIONAL COMUNISTA
}

\author{
Nation and (or) Socialism: Mariátegul, Haya de la Torre and the Communist \\ INTERNATIONAL
}

\begin{abstract}
Resumo: Este artigo procura analisar a dupla polêmica que o marxista peruano José Carlos Mariátegui sustentou em seus dois últimos anos de vida com o intelectual e líder do APRA., Víctor Raúl Haya de la Torre, por um lado, e com os representantes latino-americanos da Internacional Comunista (IC), por outro. Parto da hipótese de que esse debate lançou temas produtivos que iriam pautar o debate latino-americano ao longo do século XX, tais como: as modalidades de dominação imperialista, o conteúdo de um programa revolucionário para a região, e quais classes sociais iriam levá-la adiante. Além disso, a posição de Mariátegui entre o "localismo" de Haya de la Torre e o "cosmopolitismo" da IC revelaria as dificuldades do marxismo para interpretar as realidades da América Latina.

Palavras-chave: Marxismo; América Latina; Mariátegui; Haya de la Torre; Internacional Comunista.

Abstract: This paper analyzes the polemical debate sustained in the last two years of life of the Peruvian Marxist José Carlos Mariategui with both the intellectual and leader of the APRA., Víctor Raul Haya de la Torre, on the one hand, and the Latin American representatives of the Communist International, on the other. I start from the assumption that this debate has indicated seminal themes that would guide the Latin American debate over the twentieth century, such as the modalities of imperialist domination, the contents of a revolutionary program for the region, and which social classes would take it forward. In addition, the position occupied by Mariátegui, between the "localism" of Haya de la Torre and the "cosmopolitanism" of the Communist International, reveals the difficulties of the marxist theory to interpret the realities of Latin America.
\end{abstract}

André Kaysel ${ }^{*}$

Key words: Marxism; Latina America; Mariátegui; Haya de la Torre; Communist International.

(*) Doutorando em Ciência Política — Universidade de São Paulo. E-mail: <andrekaysel@gmail.com>. Recebido em 17.11.11 e aceito em 27.02.12. 
INTRODUÇÃO

Um dos lugares-comuns no debate em torno da história das ideias políticas e sociais na América Latina é discutir a adaptação (ou inadaptação) de teorias ou ideologias importadas da Europa ocidental para o contexto do subcontinente (Hale, 2001, p. 331). Por trás dessa perspectiva de análise, está o conceito de que a circulação e recepção das ideias está estruturada por uma lógica — análoga à da circulação de mercadorias — na qual o mundo estaria estruturado por um centro gerador e difusor de ideias, de um lado, e por uma periferia consumidora, de outro, a qual sempre procuraria adaptar ou repensar as ideias importadas do centro à luz de suas próprias realidades.

No que tange à história do marxismo na América Latina, talvez a fórmula mais forte, nesse sentido, seja a de José Aricó, para quem a teoria (marxista) e a realidade (latino-americana) "viveriam em mútua e secreta repulsão" (Aricó, 1982). Já Michael Löwy fala em duas posturas que teriam polarizado a trajetória do materialismo histórico na região: o localismo, de um lado, o qual recusaria o universalismo da teoria em nome do particularismo do real e, de outro, o cosmopolitismo, o qual submeteria qualquer particularidade ao caráter universal da teoria (Löwy, 1999, p. 9-71). Como exemplo da primeira postura, por ele considerada como "populista", o autor brasileiro aponta a figura do teórico e líder político peruano Víctor Raúl Haya de la Torre (1893-1979), fundador e principal dirigente da Aliança Popular Revolucionária Americana (APRA), o qual teria se afastado do marxismo por afirmar sua inadequação para o "espaço/tempo" da América Latina. Já como representativa da segunda postura, ele aponta a Internacional Comunista (IC), cujos representantes na região teriam aplicado de modo acrítico os esquemas do marxismo-leninismo.

Tanto para Löwy quanto para Aricó, uma das poucas figuras que, antes da Revolução cubana, teria escapado a esse desencontro teria sido o jornalista e militante peruano José Carlos Mariátegui (1894-1930), cuja apropriação do materialismo histórico como método crítico para apreender o real teria lhe possibilitado produzir interpretações originais das realidades de seu país e da região. Mais do que isso, creio que se possa dizer que há um consenso de que Mariátegui foi o principal autor marxista de toda a América Latina (Therborn, 1995).

O marxismo de Mariátegui se afirmou, justamente, em uma dupla polêmica com o "localismo" de Haya de la Torre, por um lado, e com o "cosmopolitismo" da IC por outro, buscando, assim, realizar uma síntese entre o universal e o particular, a qual possibilitaria criar um marxismo enraizado nas condições latino-americanas. Diante disso, meu objetivo neste artigo é o de analisar o debate sustentado pelo autor dos Siete Ensayos de Interpretación de la Realidad Peruana, na fase final de sua obra. Como se verá adiante, sustento que essa discussão lançou categorias, problemas e temas produtivos que iriam pautar o debate da esquerda latino-americana ao longo do século XX, tais como: as modalidades da dominação imperialista, o conteúdo de um programa revolucionário e quais classes e grupos sociais seriam seus portadores.

Além disso, acredito que a posição ocupada por Mariátegui entre Haya de la Torre e a IC ilustra bem os impasses do marxismo para lidar com uma realidade que, embora 
inserida nos quadros culturais mais amplos do chamado "ocidente", ocupa neste o papel de periferia ${ }^{(1)}$. O texto que se segue está estruturado em três partes. Na primeira, abordarei como Mariátegui, Haya e o Comintern discutiram o tema do imperialismo; na segunda sessão, reconstituirei o debate em torno do programa revolucionário defendido pelos contendores citados e os sujeitos sociais e políticos que, segundo seus esquemas teóricos, levariam as transformações adiante. Por fim, encerrarei com um breve balanço das implicações desta polêmica para o problema da relação entre o marxismo e a América Latina.

Antes, todavia, de entrar na discussão, é preciso fazer uma advertência: Mariátegui nunca sistematizou suas concepções políticas ou um programa de conjunto. Em carta ao seu companheiro Moisés Arroyo Posadas, o próprio Mariátegui dizia: "Trabalho também no livro que, sob o título de 'Ideologia e Política Nacionais', publicarei nas edições História Nueva de Madri. Este último livro, precisamente, conterá todo meu legado doutrinário e político. A ele, remeto tanto os que, nos Siete Ensayos, pretendem buscar algo que não teria porque formular em nenhum de seus capítulos — uma teoria ou um sistema políticos - , como os que, desde pontos de vista "hayistas", me reprovam o excessivo 'europeísmo' ou insuficiente 'americanismo'." (Mariátegui, 1991, p. 139)(2)

Entretanto, não só o autor não o fez, como os originais desse livro se perderam e nunca foram encontrados. Diante desta perda irreparável, só resta ao estudioso reunir os elementos de um pensamento político disperso por vários textos. Uma tal reconstrução, como não poderia deixar de ser, é muito parcial e sujeita a contestações. Mas, em que pese essas deficiências, é o único modo de abordar as concepções de Mariátegui sobre a política revolucionária, forjadas no duplo debate com os adeptos da Ação Popular Revolucionária Americana (APRA) e a Internacional Comunista (IC).

\section{Quem é o Iinimigo? O Problema do Imperialismo}

Em 7 de maio de 1924, o ex-líder da Federação dos Estudantes do Peru e da luta pela reforma universitária, Víctor Raúl Haya de la Torre, a partir de seu exílio no México, funda a Aliança Popular Revolucionária Americana (APRA). Inicialmente concebida como uma aliança continental de luta contra o imperialismo e pela unidade latino-americana, a APRA deveria ser uma frente única organizada em células nacionais. Seu modelo era o do Partido Nacionalista (Kuomintang) que conduzia a Revolução Chinesa, baseado em uma aliança que ia de setores nacionalistas burgueses até o nascente proletariado que já havia começado a se organizar no Partido Comunista Chinês.

Nesse mesmo período, a Internacional Comunista - confrontada com a derrota da onda revolucionária na Europa Central (1918-1923) — passara a observar com atenção

(1) Faço aqui a referência genérica ao "ocidente", pois, historicamente, os países da Europa ocidental e os EUA forneceram os modelos econômicos, políticos e culturais às elites latino-americanas, sendo o marxismo também parte desse contexto. Todavia, como ficará claro ao longo do artigo, o "centro" mais imediato que balizou o debate entre Haya e Mariátegui foi a recém-criada União Soviética, onde funcionava a IC como polo difusor do marxismo-leninismo para todo o mundo.

(2) Não se deve confundir o livro anunciado na carta com o volume "Ideologia e Política" das obras completas. Este é uma compilação de diversos escritos do autor feita por seus herdeiros. 
o desenrolar dos inúmeros movimentos nacionalistas e anti-imperialistas que se passavam na periferia do capitalismo. Tomando a China como modelo paradigmático, a IC elaborou uma estratégia para a luta anti-imperialista no "mundo colonial e semicolonial" que defendia a constituição de frentes anti-imperialistas em conjunto com setores nacionalistas burgueses e pequenos burgueses (Slessinger, 1974, p. 43-53).

Ao mesmo tempo, alguns grupos nacionalistas, daquilo que viria a ser chamado de Terceiro Mundo, simpatizavam com a IC por suas declarações incisivas contra o imperialismo - a partir da "Conferência de Baku" em 1921 —, além de acompanharem com interesse os primeiros passos da União Soviética rumo à industrialização. Afinal, tratava-se de um país de estrutura socioeconômica atrasada que se propunha a se modernizar sem passar por uma etapa de pleno desenvolvimento capitalista.

Um desses nacionalistas da periferia foi justamente Haya de la Torre, o qual, em 1924, esteve na URSS. Da experiência soviética, Haya extrairia um modelo de industrialização, a partir da planificação estatal, e a concepção de partido leninista centralizado, os quais teriam grande impacto na posterior teorização do aprismo (Montesinos, 2000, p. 26) ${ }^{(3)}$.

Todavia, o fundador do APRA não era, nem nunca seria, um marxista ortodoxo. Aliás, o pensamento de Haya se constituiu em aberto confronto com este, o qual considerava inadequado para compreender a realidade latino-americana. Para ele, o uso do marxismo pela intelectualidade latino-americana era mais um exemplo de importação ideológica, como se pode ver pela seguinte passagem: "Nossos ambientes e nossas transplantadas culturas modernas não saíram ainda da etapa prístina do transplante. Com ardor fanático, tornamos nossos, sem nenhum espírito crítico, apotegmas e vozes de ordem que nos chegam da Europa. Assim, agitamos fervorosos, há mais de um século, os lemas da Revolução Francesa. E assim podemos agitar hoje as palavras de ordem da Revolução Russa ou as inflamadas consignas do fascismo. Vivemos em busca de um padrão mental que nos libere de pensar por nós mesmos." (Haya de la Torre, 2000, p. 49)

Sua formação, portanto, recorria a fontes mais variadas, incluindo, por exemplo, o evolucionismo, o positivismo e a física relativista de Einstein que tinha grande repercussão no período ${ }^{(4)}$. Foi justamente dessa última fonte que retirou o conceito de espaço/ tempo histórico relativo.

A Indo-América viveria em um outro espaço/tempo - o do feudalismo - , diferente do da Europa - o capitalismo. Desse modo, se o marxismo era uma doutrina aplicável à realidade europeia, pois pertencia a seu espaço/tempo histórico, não o seria para a realidade indo-americana.

Um bom exemplo dessa combinação de relativismo espaço/temporal e evolucionismo é fornecido pela concepção de Haya de la Torre a respeito do fenômeno imperialista:

(3) Para além dessas influências, pode-se acrescentar que a IC forneceu a Haya, bem como a outros nacionalistas radicais latino-americanos como o venezuelano Rómolo Betancourt, um vocabulário e um aparato conceitual com os quais pensar suas realidades sociais (Caballero, 1988, p. 25).

(4) Para a repercussão da ideia de Einstein, segundo a qual espaço e tempo seriam categorias relativas, bem como de outras novas correntes filosóficas no pensamento latino-americano da década de vinte, cf. Funes, 2006, p. 45-68 e 75-79. 
"O aprismo, sintetizando seus pontos de vista teóricos, considera que o imperialismo, última etapa do capitalismo nos povos industriais, representa, entre os nossos, a primeira etapa. Nosso capitalismo nasce com o advento do imperialismo moderno. Nasce, pois, dependente e como resultado da culminação do capitalismo na Europa, Inglaterra especialmente." (idem, p. 63)

Dessa maneira, se o autor endossa a famosa definição leninista do imperialismo como "fase superior do capitalismo", ele a restringe à Europa e ao espaço-tempo do capitalismo avançado. Na Indo-América, o imperialismo teria sido, ao contrário, a "primeira fase" do capitalismo.

Nessa chave, o imperialismo seria não apenas uma etapa histórica incontornável, como também teria seu lado benéfico, por trazer às economias indo-americanas a técnica e os métodos produtivos modernos. O capitalismo seria uma etapa histórica destinada a ser substituída por outra - o socialismo - mas seria um degrau do desenvolvimento histórico inescapável para todas as sociedades humanas.

Diante desse diagnóstico, o fundador da APRA rejeitava as teses que sustentavam, de um lado, a superação da dependência econômica por meio de uma revolução socialista ou, por outro, a conciliação da independência com o desenvolvimento capitalista. No primeiro caso, ignorar-se-ia o caráter embrionário do capitalismo latino-americano, conforme enunciado acima. Já no segundo, desconhecia-se o obstáculo representado pelos capitais imperialistas, os quais não admitiriam a competição dos países da região (idem, p. 61-62).

Para Haya, a solução do impasse estaria na constituição de um Estado anti-imperialista, o qual, por meio de uma progressiva nacionalização das fontes de produção, regularia os intercâmbios do país com o exterior, impedindo o capital imperialista de ameaçar a soberania nacional. Esse Estado seria, em sua visão, um órgão de defesa das classes produtoras - camponeses, operários e classes médias - , assunto ao qual retornarei na próxima sessão (idem, p. 65). Para que o Estado fosse bem-sucedido nessa função de defesa econômica seria fundamental a unidade política da América Latina para evitar que o imperialismo pudesse, diante do controle que um país pretendesse exercer sobre seus investimentos, escolher outro que lhe abrisse as portas (idem, p. 64)

Eis aí o caráter do anti-imperialismo aprista: estabelecer a dinâmica e o controle do desenvolvimento capitalista a partir "de dentro", afirmando-se a soberania nacional por meio da ação planificadora do Estado.

Como lembram Galindo e Burga, a atuação do imperialismo no Peru — país cuja economia era marcada, de um lado, pelos enclaves mineiros e, de outro, pela agricultura de exportação - gerou uma forte reação sob a forma de um marcado nacionalismo econômico. O caráter desse nacionalismo, todavia, não era unívoco e dependia das diferentes classes que o expressavam. A liderança desse movimento nacionalista foi, no final dos anos 20, disputada por Haya de la Torre e Mariátegui, os quais plasmaram suas versões mais duradouras (Galindo e Burga, 1994, p. 125).

Em "Punto de Vista Anti-Imperialista" — que, ao lado de "El Problema de Las Razas en América Latina", foi enviada pelo revolucionário peruano como contribuição à 
I Conferência Comunista Latino-americana - Mariátegui começa por propor uma diferenciação interna entre os chamados países "semicoloniais". De um lado, haveria aqueles que vivenciam a intervenção política e militar direta do imperialismo e onde, por conseguinte, a burguesia e a pequena burguesia podem assumir uma postura nacionalista ou anti-imperialista. De outro, haveria países nos quais, em que pese o caráter semicolonial da economia, a burguesia se sentiria suficientemente dona do poder político para não se preocupar com a soberania nacional, associando-se ao capital estrangeiro sem reservas (Mariátegui, 1991g, p. 202).

Dentro da América Latina, também existiria a divisão acima mencionada. De um lado, na América Central — cujas Repúblicas tinham a experiência da intermitente intervenção militar norte-americana - poderiam se desenvolver movimentos cujo eixo seria o anti-imperialismo e a libertação nacional. De outro, na América do Sul, cujas burguesias não se sentiam ameaçadas pelo imperialismo, o anti-imperialismo só poderia ser coerentemente sustentado por movimentos classistas (idem, p. 206).

Para o autor: "Nem a burguesia, nem a pequena burguesia no poder podem fazer uma política anti-imperialista consequente. Temos a experiência do México, onde a pequena burguesia acabou pactuando com o imperialismo yankee." (idem, p. 205)

Essa última passagem, referindo-se ao caminho tomado pela Revolução Mexicana, retoma claramente o diálogo com Haya de la Torre, para o qual a Revolução ocorrida no México a partir de 1910 seria o modelo de uma revolução anti-imperialista. Ao contrário deste, Mariátegui não acreditava que o anti-imperialismo pudesse ser o cerne de um programa revolucionário, devendo este basear-se na luta de classes e no socialismo.

Quanto à pequena burguesia e a aposta que o líder aprista fazia em seu potencial revolucionário, o marxista sustenta que seus interesses concretos não são necessariamente antagônicos aos do imperialismo. Ao contrário, com o crescimento da presença de empresas multinacionais, as classes médias urbanas viam aumentar suas possibilidades de emprego e ascensão social, fugindo à "empregomania" que a atrelava aos pequenos cargos públicos (idem, p. 208).

Por fim, Mariátegui questiona uma tese cara à IC: a de que os interesses imperialistas coincidiam necessariamente com os da aristocracia feudal. Embora concordando que o capital imperialista se apoiava na classe feudal, por identificar nela a elite política, ele não via aí uma coincidência necessária de interesses. Pelo contrário, a expansão do capital financeiro internacional acarretava mudanças que, em longo prazo, punham em cheque os interesses materiais dos latifundiários feudais, por generalizar as relações capitalistas na economia. Por outro lado, o capital estrangeiro preferiria aliar-se a uma classe social mais numerosa e, por isso, capaz de garantir a ordem social: caso da burguesia nacional e da classe média (idem, ibidem).

Esse texto demarca, dessa maneira, dois interlocutores: de um lado, Haya de la Torre e o aprismo são seu alvo explícito e, de outro, as teses do Comintern também são questionadas.

Dessa forma, embora diretamente endereçada ao APRA, a tese de Mariátegui questiona importantes pressupostos da política da IC para a região. Afinal, punha por terra a tese de que a revolução latino-americana teria de passar por uma etapa "democrático- 
-burguesa". Partindo de uma análise concreta de situações concretas, o autor peruano afirma não haver oposição de interesses entre a burguesia nacional e o capital financeiro internacional, defendendo o caráter socialista e proletário da revolução. É curioso notar que, se nos conceitos de fundo, a IC e Mariátegui se aproximam entre si e se distanciam de Haya, a primeira está mais próxima do último no que tange ao diagnóstico do papel progressista que a burguesia nacional teria em relação ao imperialismo.

Uma boa ilustração dessa discrepância está no debate, entre os representantes da IC e a delegação peruana na Conferência de Buenos Aires, em torno da questão de Tacna e Arica. Essas duas províncias foram arrebatadas ao Peru pelo Chile durante a "Guerra do Pacífico" (1879-1884). Embora um plebiscito tivesse sido acordado para que os habitantes da região decidissem sobre a que Estado desejavam ser ligados, o Chile adiara constantemente sua realização, o que era motivo de recorrentes tensões tanto entre os dois países, quanto nas províncias em litígio. A IC, aplicando a tese leninista da autodeterminação dos povos, colocara a realização do plebiscito como uma importante bandeira de luta. Como o recém-fundado Partido Socialista Peruano parecia não conferir a mesma prioridade à realização do plebiscito, o encarregado do Secretariado Sul-americano da IC (SSAIC), o ítalo-argentino Vittorio Codovilla, admoestou publicamente os delegados do Peru (Galindo, 1994, p. 405-406). Diante de tais críticas, Hugo Pesce, delegado do PSP no encontro, replicara que a realização do plebiscito não interessava, no momento, aos trabalhadores peruanos, mantendo-se estes alheios à "agitação patriótica" promovida pela burguesia e pela pequena burguesia. Essa afirmação foi precedida pelo seguinte comentário do delegado peruano: "Nós, comunistas, devemos estudar um ponto importantíssimo: qual tem sido a posição das distintas camadas sociais frente a um conflito determinado." (apud idem, p. 406)

Independente do mérito da questão, a divergência em torno de Tacna e Arica, ilustra o modo diferente pelo qual os peruanos e a IC pensavam o problema do imperialismo e sua relação com as classes sociais no Peru. Enquanto a IC aplicava a fórmula dos "países coloniais, semicoloniais e dependentes" a toda a América Latina de modo indistinto, os peruanos, sob a égide intelectual de Mariátegui, procuravam entender a especificidade da penetração imperialista na sociedade peruana e as relações concretas entre esta e as diferentes classes sociais. Como se verá a seguir, tal divergência de método, que se expressou na conferência, irá além do problema do imperialismo e afetará questões como o caráter do partido e a teoria da revolução.

\section{As tarefas da Revolução e Seus Sujeitos}

Na nota introdutória aos Siete Ensayos de Interpretación de la Realidad Peruana, seu mais importante livro, Mariátegui se defende da acusação segundo a qual seria um "europeizante". Afirma não haver saída para o Peru "fora das ideias e da técnica ocidentais". Por fim, menciona Sarmiento, o qual, "sendo europeizante ele também, não encontrou melhor forma de ser argentino" (idem, 2008, p. 6).

A quem essas linhas eram endereçadas? A resposta pode ser encontrada se se tiver em mente que, no mesmo ano em que o autor publicava os Siete Ensayos..., ele rompia 
com seu antigo aliado Haya de la Torre e os demais seguidores do aprismo. Na sessão anterior, foram apresentadas as divergências entre os dois intelectuais e militantes peruanos no que tange ao imperialismo e sua relação com as classes sociais. É o caso, agora, de aprofundar a questão e discutir os termos básicos que balizaram a polêmica entre Haya e Mariátegui.

No Discurso/Programa de 1931, Haya de la Torre começa falando nas "duas economias" que caracterizariam a formação social, não apenas do Peru, mas da Indo-América em geral. De um lado, haveria um setor nacional da economia, predominantemente feudal, agrário e técnica e socialmente atrasado. O outro, estaria ligado ao mercado mundial pelo predomínio imperialista, integrado pela produção de matérias-primas e produtos semiprocessados de exportação (tanto agrícolas como minerais).

O grande dilema nacional estaria na polaridade entre esses dois setores econômicos. O centro do programa Aprista estaria, portanto, na superação dessa dualidade básica que cindia a sociedade peruana e a impedia de se afirmar como nação (Haya de la Torre, 2000a, p. 172-173) ${ }^{(5)}$.

Se este era o caráter da Revolução Nacional, quais seriam seus agentes? Ou, de outro modo, sendo o aprismo a teoria e a prática dessa Revolução, quem seriam suas bases sociais?

Para Haya de la Torre, a base social da Revolução seria integrada pelo proletariado, os camponeses e pela classe média, cabendo a liderança a esta última (idem, 2000 b, p. 64). Novamente, o autor demarca suas divergências com o marxismo de matriz leninista. Sendo a industrialização do Peru embrionária — restrita à mineração e a produtos semiprocessados - não haveria no país o proletariado maduro que Marx considerava a classe revolucionária. Além de muito reduzido, o operariado local seria muito jovem e não teria a possibilidade material de assumir aquele papel histórico. Quanto ao campesinato, pela servidão e atraso cultural e tecnológico em que vivia, estava também impossibilitado de assumir o protagonismo político. Já a massa de pequenos proprietários e "trabalhadores intelectuais" era vista por Haya como elemento fundamental dessa aliança policlassista, pois além de ser prejudicada pelo imperialismo, tinha as condições - ausentes entre as duas primeiras classes - de exercer um papel de liderança no novo Estado.

Assim, a aliança entre operários, camponeses e a classe média formaria o pilar do "Estado Anti-imperialista", o qual deveria dirigir o processo de desenvolvimento capitalista autônomo do Peru. Nas palavras de Haya de la Torre: "Depois de derrubado o antigo Estado feudal, o movimento anti-imperialista organizará sua defesa, estabelecendo um novo sistema de economia, cientificamente planejada, e um novo mecanismo estatal que não poderá ser o do Estado democrático livre, mas sim o de um Estado de guerra, no qual o uso da liberdade econômica deve ser limitado para que não se exercite em benefício do imperialismo." (idem, 2000c, p. 57)

(5) Discurso proferido em Lima, em agosto de 1931, durante comício de Haya em sua campanha para Presidente da República. 
É preciso frisar aqui que, ao falar em "Estado de guerra", o autor se refere à luta constante para controlar os interesses econômicos do capital estrangeiro e, assim, salvaguardar a soberania nacional. É nesse mesmo sentido que defende a restrição da liberdade de iniciativa econômica e o controle nacional sobre a produção (idem, p. 56). No plano político, defende a adoção do que denomina como "democracia funcional": isto é, um critério de representação política baseada nas categorias produtivas.

Em seguida, o autor diz, explicitamente, que o Estado anti-imperialista tem semelhanças com o capitalismo de Estado, praticado na Europa da Primeira Guerra Mundial. A diferença entre ambos seria que, enquanto o segundo seria uma medida de urgência para proteger o capital imperialista, o primeiro seria a base para criar um novo sistema econômico, fundado no controle progressivo da produção pelo Estado, que beneficiaria as já mencionadas classes produtoras que compunham a base do novo regime (idem, p. 58-59).

Assim, se o líder do aprismo concordava que a América Latina vivia uma transição do feudalismo para o capitalismo, se afastava da III Internacional ao qualificar qual seria o caráter do imperialismo e, por conseguinte, da revolução anti-imperialista. Divergia, também, sobre quais seriam as forças sociais a encabeçar o processo, ou seja, sobre quais seriam as bases do partido revolucionário.

Como se verá mais adiante, contrapondo esses postulados com a obra de Mariátegui, fica claro que este último não compartilhava essa caracterização dualista da economia peruana, bem como a visão evolucionista do processo histórico que apoiava a teoria da revolução de Haya de la Torre. Estaria, como de fato foi o caso, mais conforme, a esse respeito, com a leitura leninista, embora, o evolucionismo do aprista era mais próximo da formulação da IC a respeito da realidade latino-americana.

Essas divergências entre apristas e comunistas foram mantidas em segundo plano até o Congresso Mundial Anti-imperialista de Bruxelas (realizado em fevereiro de 1927), no qual as relações foram rompidas de ambos os lados. As distâncias cresciam à medida que Haya disputava com as Ligas Anti-imperialistas (organizadas pelos comunistas) a liderança do movimento anti-imperialista na América Latina. Isso o levou a afirmar o APRA como organização continental "sem influência estrangeira" e a criticar os comunistas por aplicarem à região a linha política emanada da Europa (Montesinos, 2000, p. 34-35).

A ruptura entre a APRA e a IC não levou, de modo imediato, a um confronto análogo entre Haya e Mariátegui. O primeiro abalo viria no início do ano seguinte, quando Haya de la Torre comunica - a partir do México e sem consultar a célula aprista do Peru - sua decisão de transformar a APRA em um partido nacionalista peruano - o Partido Nacionalista Libertador (PNL) - e lançar-se como candidato à Presidência da República ${ }^{(6)}$.

(6) O novo partido, entretanto, só viria a ser fundado de fato em 1931, com o nome de Partido Aprista Peruano, PAP., todavia, continuou a ser conhecido como el APRA. Aqui fiz a opção por manter a sigla APRA, mas mudar o gênero para o masculino dado que a organização passou de uma aliança para um partido. 
Confrontado com essa decisão, Mariátegui a questionou em carta enviada à célula aprista do México em abril de 1928. Nela, o marxista rejeita totalmente a ideia de criar um Partido Nacionalista Peruano sem enraizamento popular, pois a considerava uma tática típica da "velha política" e estranha aos fins do movimento aprista (Mariátegui, 1991b, p. 130-131). A ruptura se dará em maio, após a resposta de Haya, na qual este acusa Mariátegui de "europeísta" e exige que se discipline, "não com a Europa revolucionária”, mas "sim com a Indo-América revolucionária” (Quijano, 1991, p. 122).

O rompimento é publicamente confirmado no editorial do segundo aniversário de Amauta: "Aniversário y Balance", publicado no número de 17 de setembro de 1928. Vale a pena deter-se neste artigo pois ele explicita os elementos teóricos de fundo que nortearam a polêmica dos dois revolucionários peruanos. Tratava-se, para Mariátegui, de negar a tentativa de seu interlocutor de postular um caminho original para a revolução latino-americana, afirmando a inserção da América Latina em um processo histórico universal, pautado pelo conflito entre capitalismo imperialista e socialismo: "A mesma palavra 'revolução', nesta América das pequenas revoluções, se presta bastante a equívocos. (...) Temos que restituir-lhe seu sentido estrito e cabal. A Revolução Latino-americana será nada mais e nada menos que uma etapa, uma fase da Revolução Mundial. Será, simples e puramente, a Revolução Socialista." (Mariátegui, 1991a, p. 126)

Para o autor, o socialismo "pressupunha e abarcava" todos os adjetivos que podiam ser adicionados à revolução: "nacional", "agrarista" ou "anti-imperialista" (idem, ibidem). Assim, o socialismo aparecia como única possibilidade de emancipação para a América Latina, a qual chegara tardiamente à competição internacional, numa era de "monopólios e de impérios". No capitalismo contemporâneo, portanto, a região "só poderia ter o papel de colônia". "Esta civilização (a ocidental) conduz, com forças e meios dos quais nenhuma dispôs anteriormente, à universalidade. Nesta ordem mundial, a Indo-América pode e deve ter individualidade e estilo, mas não uma cultura e um destino particulares." (idem, p. 127) Três anos antes da polêmica com Haya, em um texto de crítica ao pensador argentino Alfredo Palácios, Mariátegui já assumia essa linha de raciocínio ao afirmar que, ao invés de uma crise da cultura europeia ou ocidental, o que se vivia era uma crise do capitalismo, sendo a ordem emergente, o socialismo, também um produto do ocidente (idem, 1991f, p. 366). Em suma, tomar parte no movimento histórico universal não exclui fazê-lo a partir de características e linguagem próprias. Daí a insistência do autor no caráter "original" que deveria ter o socialismo na região. Daí também a lembrança reiterada do antecedente autóctone que haveria para o socialismo moderno: o comunismo primitivo incaico (idem, 1991a, p. 127).

O autor marxista tem como preocupação central pensar uma estratégia socialista que seja adequada às condições históricas específicas, não apenas de seu país, mas da Indo-América como um todo. Em outra passagem do mesmo editorial, Mariátegui afirma: "O socialismo indo-americano não deverá ser decalque nem cópia, mas sim criação heróica." (idem, p. 128) Em seguida, o texto vincula essa originalidade, no caso peruano, ao potencial, para a futura organização de uma economia socialista no país, do ayllú e dos hábitos coletivistas do índio quechua. 
Se Haya de la Torre apontava o particularismo da realidade latino-americana para negar validade ao universalismo da teoria marxista, Mariátegui procura conciliar as pretensões universalizantes do método materialista com a particularidade da situação latino-americana. De um lado, o líder aprista - reivindicando a originalidade da realidade do subcontinente - afirmava a necessidade de um caminho próprio para a revolução na América Latina e, de outro, Mariátegui apontava a inserção da região no quadro do desenvolvimento histórico universal para defender, mesmo que reconhecendo suas especificidades, a vinculação entre a revolução latino-americana e a revolução socialista mundial.

É justamente essa diferença teórica de fundo que instrui suas discrepâncias em relação ao caráter do imperialismo na região, a constituição e papel político das classes sociais, bem como ao programa revolucionário a ser seguido. Como afirma Quijano, a polêmica entre os dois delineia as duas correntes que iriam, nas próximas décadas, disputar a hegemonia do movimento revolucionário do Peru: de um lado, a nacionalista-democrática e, de outro, a socialista-marxista (Quijano, 1991, p. 122).

Mais do que isso, como lembra Patrícia Funes, essa polêmica entre Haya e Mariátegui antecipa, em grande medida, os termos em que se daria o debate, nas décadas seguintes, entre nacional-populistas e comunistas e entre adeptos da CEPAL e da Teoria da Dependência (Funes, op. cit, p. 245-246).

Embora tanto Haya de la Torre quanto Mariátegui se reportem à nação e ao nacionalismo, eles o fizeram de modo distinto. Se o primeiro, como ficou claro acima, defendia a construção da nação por meio de um "capitalismo de Estado", com base em um arranjo policlassista, o segundo sustentava que a autonomia nacional só poderia se dar com a ruptura com o capitalismo. Nesse sentido, afirma no segundo capítulo dos Sete Ensaios...: "Neste instante de nossa história, não há como ser nacionalista e revolucionário sem ser socialista." (Mariátegui, 2008, p. 28) Assim, onde Haya de la Torre procura distinguir ou opor nacionalismo e socialismo, seu interlocutor tenta uni-los. Cerca de um ano antes do rompimento com o líder do APRA, no segundo artigo de uma polêmica com Luis Alberto Sánchez — que, diga-se de passagem, após 1931, se filiará ao aprismo - Mariátegui precisa esse raciocínio: "O nacionalismo das nações européias, onde nacionalismo e conservadorismo se identificam e se consubstanciam, se propõe fins imperialistas, sendo reacionário e anti-socialista. Mas o nacionalismo dos povos coloniais, sim, coloniais economicamente, ainda que se vangloriem de sua autonomia política, tem uma origem e um impulso totalmente diversos. Nesses povos o nacionalismo é revolucionário e, portanto, concluí-se no socialismo. Nesses povos a ideia da nação não cumpriu ainda sua trajetória nem esgotou sua missão histórica." (idem, 1995b, p. 250) ${ }^{(7)}$

Dessa maneira, Mariátegui não acreditava que os problemas nacionais pudessem ter uma solução burguesa e liberal. Sem dúvida que os problemas fundamentais do Peru eram problemas de uma revolução burguesa: emancipação nacional, reforma agrária, integração social e política da massa popular, sem as quais não poderia haver nação sólida.

(7) Publicado em Amauta, número 7, março de 1927. 
Contudo, uma burguesia retardatária e formada pela associação entre o imperialismo e o latifúndio seria historicamente incapaz de levar a cabo as tarefas que suas congêneres haviam cumprido alhures.

A missão histórica de completar o processo de formação da nação caberia a uma aliança entre o nascente proletariado industrial e o campesinato indígena, a qual levaria a cabo uma revolução de caráter socialista. Se a liderança revolucionária caberia aos operários, os indígenas seriam a base social sem a qual nenhuma revolução poderia triunfar nas condições peruanas.

Aqui, estou de acordo com Aricó, que aí percebe a tentativa de Mariátegui de "traduzir" para as condições históricas peruanas a estratégia de Lênin para a Revolução Russa (Aricó, 1978, p. XLVIII). A posição aprista diante da pretensão mariateguiana de pensar um caminho socialista para o Peru e a América Latina pode ser bem sintetizada pelo artigo do dirigente aprista Carlos Manuel Cox. Para ele, no que tange à interpretação marxista da realidade peruana, Mariátegui e o aprismo estão de acordo. A divergência surgiria, segundo ele, no adjetivo (Cox, 1978, p. 4) ${ }^{(8)}$. O problema do autor dos Siete Ensayos, segundo o companheiro de Haya de la Torre, seria seu excessivo "intelectualismo", que o levaria a desconhecer as necessidades próprias à ação política.

Desse modo, Mariátegui teria se deixado levar pelo impacto de sua experiência na Europa - à qual soubera analisar de modo acurado - e "imaginado" para o Peru e para a Indo-América um proletariado revolucionário que, na realidade, não existiria. Assim, termina julgando o legado mariateguiano com uma paráfrase de Ortega y Gasset: "tens razão em tudo o que negas, mas te equivocas em muito do que afirmas." (idem, p. 8)

Cox recolhe de Haya o tema da adequação da teoria à realidade e do "europeísmo" de Mariátegui, ao mesmo tempo que procura reivindicar para o APRA seu legado como intérprete da realidade peruana. Como se depreende da análise feita acima, o juízo de Cox de que a discordância seria somente "adjetiva" é errôneo. Seu próprio artigo deixa isso claro ao afirmar que a visão europeizante e intelectualista de Mariátegui o teria impedido de discernir as diferenças na estrutura social entre a Europa e a América Latina (idem, p. 7).

Há, todavia, um aspecto interessante e acertado do texto do dirigente aprista: sua afirmação da divergência de Mariátegui com relação à III Internacional. Embora se equivocando em fatos e datas, Cox aponta como o Partido Socialista de Mariátegui, embora pretendesse filiação à IC, foi rejeitado pela mesma por seu "revisionismo" (idem, p. 7-8). É, justamente, para essa outra polêmica que me voltarei agora.

Após a ruptura com Haya, o Grupo de Lima - formado por intelectuais e sindicalistas reunidos em torno de Mariátegui e de Amauta —, se lança à organização do Partido Socialista do Peru, fundado em 26 de setembro de 1928 e tendo Mariátegui como seu secretário-geral. Encarregado, pelo Comitê Organizador do partido, para redigir uma declaração de princípios, José Carlos Mariátegui afirma, em clara continuação da polêmica com Haya: "O Partido Socialista do Peru adapta sua prática às circunstâncias concretas

(8) Publicado em Claridad, número 279, Buenos Aires, julho de 1930. p. 4. 
do país, mas obedece à uma ampla visão de classe, segundo a qual, as mesmas circunstâncias nacionais estão subordinadas ao ritmo da história mundial." (Mariátegui, 1991i, p. 153) Mais adiante, ao caracterizar a etapa imperialista do capitalismo, sustenta: "A práxis do socialismo neste período é a do marxismo-leninismo. O marxismo-leninismo é o método revolucionário da etapa imperialista e dos monopólios." (idem, p. 154)

Desse modo, ao se distanciar do APRA., o grupo de Lima reivindicava sua filiação à III Internacional ao afirmar sua adesão ao marxismo-leninismo: isto é, ao marxismo de matriz comunista. Contudo, as relações de Mariátegui com a IC não eram tranquilas.

Este tema é um tópico controverso que divide os intérpretes de sua obra. Alguns como Jorge Del Prado e Jorge Falcón — ligados ao Partido Comunista Peruano (PCP), sustentam que as discrepâncias foram secundárias ou de menor importância (Del Prado, 1978, p. 84-86; Falcón, 1985, p. 26-28). Já outros, como Quijano, Alberto Flores Galindo, Aricó e Antonio Melis, adotam o ponto de vista oposto: o de que Mariátegui e a IC tinham divergências de fundo que teriam levado o marxista peruano ao isolamento, tanto no movimento comunista latino-americano, quanto em seu próprio partido.

Mesmo sendo inegável que Mariátegui tenha sido parte da tradição política comunista, isso não deve obscurecer o caráter heterodoxo de seu pensamento, o qual recebeu reprovações explícitas dos representantes do Comintern. Para demonstrá-lo, é fundamental retornar à trajetória e aos termos do debate do peruano com a ortodoxia. Pouco antes do enfrentamento entre Mariátegui e Haya de la Torre, os representantes do Comintern na América Latina vinham exortando Mariátegui a romper com Haya e a fundar um Partido Comunista no Peru ${ }^{(9)}$.

As razões para evitar — em 1927 - a ruptura com o APRA são dadas pelo próprio Mariátegui. Desde seu regresso da Europa, em 1923, pretendia fundar um partido operário de orientação socialista (Mariátegui, 1995a, p. 202). Todavia, sabia que o movimento operário e popular do Peru ainda estava em seus inícios: tendo feito sua primeira aparição mais importante nas greves e manifestações estudantis de 1918-1919. Nessas condições, viu na fundação da APRA. a criação de uma frente única capaz de aglutinar os intelectuais radicais e os operários. Foi nesse mesmo espírito que fundou, em 1926, a revista Amauta: "(...) como órgão deste movimento, como tribuna de definição ideológica (...).” (idem, ibidem)

Assim, o jornalista e militante peruano, coerentemente com essa linha política, não acreditava haver as condições para fundar, em seu país, um Partido Comunista que pudesse ter enraizamento social. A transformação, no ano seguinte, do movimento aprista de frente única em partido político obrigou-o a adiantar seus planos e fundar, com os membros do "Grupo de Lima", o Partido Socialista do Peru (idem, p. 203).

Consumada a ruptura e fundado o novo partido, nem por isso as relações se tornaram harmônicas. Tais divergências se aprofundariam e ficariam mais claras na já

(9) Na Conferência da Internacional Sindical Vermelha de fins de 1927 para a qual Mariátegui enviou Julio Portocarrero e Armando Bazán, o dirigente comunista Losowsky já exortava os delegados peruanos a romper com o APRA e fundar em seu país um Partido Comunista. Cf. Quijano, 1991, p. 197. 
mencionada $1^{\underline{a}}$ Conferência Comunista Latino-americana, realizada em Buenos Aires em junho do ano seguinte. Mariátegui redigiu duas teses para o evento: "Punto de Vista Anti-imperialista" e "El Problema de las Razas en América Latina". Por motivos de saúde, o secretário-geral do PSP não pôde comparecer à conferência, sendo o médico Hugo Pesce e o sindicalista Julio Portocarrero os delegados peruanos.

$\mathrm{Na}$ tese sobre o problema racial, seu autor vinculava o potencial revolucionário dos indígenas à sua condição de camponeses (idem, 1991e, p. 216-218). Nesse sentido, a "questão indígena" se resolveria com o acesso à terra e não, como sustentavam os documentos da IC, com a concessão aos indígenas do Direito de Autodeterminação: isto é, do direito de constituírem seus próprios $\operatorname{Estados}^{(10)}$.

Mas, no que tange ao problema indígena, a principal crítica da ortodoxia comunista a Mariátegui ficou por conta de sua defesa de que o Ayllú pudesse ser aproveitado como germe de uma economia socialista autóctone. Essa tese indigenista - mesmo que acompanhada da afirmação de que não se tratava de uma defesa da volta ao passado - foi considerada como sendo "populista", no sentido do populismo russo.

O mais conhecido porta-voz dessa leitura de Mariátegui foi o especialista soviético em América Latina V. M. Miroshevsky. Segundo ele: "Mariátegui acreditava que o Peru marcharia para a Revolução por um caminho próprio, por um caminho especial. Considerava os camponeses indígenas peruanos como "coletivistas naturais", acreditava que estes realizariam a revolução socialista independentemente, sem o proletariado revolucionário" (Miroshevsky, 1978, p. 58).

Como se pode depreender da análise feita até aqui, da obra mariateguiana, a afirmação do autor soviético de que o peruano defendia uma revolução camponesa sem o proletariado é inteiramente equivocada. Não que as analogias que Miroshevsky vê entre Mariátegui e os narodniks sejam inteiramente desprovidas de razão. O problema é estigmatizá-las como "socialismo pequeno burguês" (idem, p. 69). Merece destaque, a esse propósito, a menção que Miroshevsky faz ao "caminho próprio" defendido por Mariátegui. Para a ortodoxia soviética, como se verá adiante, era a ideia de um caminho próprio ao socialismo que parecia inaceitável.

No que tange à outra grande polêmica - a do imperialismo - as referências ao debate com Haya mostraram como Mariátegui, embora centrando fogo nas concepções apristas, critica também a visão da IC de que as burguesias nacionais teriam interesses contrários aos do capital financeiro internacional.

Por fim, entre as polêmicas que opuseram o SSAIC e os representantes peruanos esteve a do caráter do novo partido. A nova agremiação não assumira a forma de um Partido Comunista, o que foi expresso na adoção do nome "socialista", de caráter mais genérico. No manifesto de fundação, acima citado, se diz: "De acordo com as condições

(10) Nesse tocante, diante das ponderações de Pesce de que a autodeterminação dos indígenas era algo alheio à realidade concreta, o representante do Secretariado da IC, Stepanov, admitiu que o problema indígena era complexo e que, talvez, a consigna mais adequada fosse a luta pela terra. Apesar disso, a maioria dos representantes da IC se mantiveram fiéis à reivindicação da autodeterminação. Cf. Quijano, 1991, p. 199. 
concretas atuais do Peru, o comitê concorrerá à organização de um partido socialista, baseado nas massas operárias e camponesas organizadas." (Mariátegui, 1991i, p. 157)

Segundo Leila Escursim, a questão do nome do partido era secundária, já que a organização adotava expressamente a ideologia "marxista-leninista" e buscava filiação à IC, sendo, na prática, um partido comunista (Escursim, 2005, p. 275-276) ${ }^{(11)}$. Não creio que isso seja preciso. Em primeiro lugar, Mariátegui sabia muito bem que a denominação "comunista" era uma das 21 condições que os Estatutos da Internacional exigiam para a filiação de um partido. Além disso, segundo Galindo, os representantes da IC, Codovilla à frente, foram incisivos ao criticar a denominação da organização. É sabido como o nome "socialista" tinha então para os comunistas uma conotação pejorativa, associada ao reformismo.

Ora, por que um intelectual assumidamente revolucionário e simpático ao Comintern como Mariátegui preferira essa denominação? Para entender suas razões, deve-se atentar para o começo e o fim da citação anterior. A prioridade do marxista peruano era a de fundar um partido que estivesse "em acordo com as condições do Peru" e que fosse "inserido no movimento das massas populares", ou seja, nas "condições concretas" do país, um Partido Comunista exclusivamente operário, como queria a IC, seria, na visão mariateguiana, algo deslocado e inviável. Daí a opção por adotar o nome mais genérico de "socialista".

Além do nome, os dirigentes da IC questionavam a composição de classe do PSP. Como se viu acima, em seu manifesto de criação o partido se dizia "baseado nas massas operárias e camponesas", além disso, o mesmo texto declarava: "A organização sindical e o Partido Socialista, por cuja formação trabalharemos, aceitarão contingentemente uma tática de frente única ou aliança com organizações ou grupos da pequena burguesia, sempre que estes representem um movimento de massas e com objetivos e reivindicações concretamente determinadas." (Mariátegui, 1991i, p. 158) ${ }^{(12)}$

Naquele período, todavia, a IC, já sob hegemonia stalinista e tendo adotado - em seu VI Congresso (1928) - a linha de "classe contra classe", estava empenhada em "proletarizar" os PCs, combatendo, em especial, os quadros intelectuais de origem pequeno burguesa, tidos como "vacilantes". Assim, homens como Codovilla consideravam o PSP uma organização demasiado aberta e flexível, o que não correspondia a seus padrões de disciplina revolucionária.

Com isso, se pode compreender o que estava por trás da polêmica em relação ao nome e caráter do PSP: a IC temia a excessiva independência da nova organização e de seu principal dirigente, preferindo o alinhamento automático com suas decisões.

Se Mariátegui parte, para o emprego do materialismo histórico, da análise de situações concretas, os membros mais ortodoxos da Internacional aplicavam os conceitos e

(11) Embora com uma análise cuidadosa e sem a linguagem panfletária das passagens citadas de Del Prado e Falcón, a autora brasileira se aproxima, nesse tocante, às posições destes últimos.

(12) Por essa declaração, vê-se como, apesar de ter rompido com Haya, Mariátegui não queria afastar a possibilidade de alianças ou convergências futuras. 
categorias do marxismo-leninismo à qualquer situação histórico-social, sem respeito por suas singularidades ${ }^{(13)}$. Essa imposição de modelos a priori a realidades estranhas aos mesmos poderia ser descrita, retomando a sugestão já mencionada de Löwy, como "cosmopolita", sendo o exato oposto do "localismo" de Haya de la Torre. Sua forma mais acabada e extrema pode ser encontrada na resposta que o Secretário Sul-americano da IC, o argentino Vittorio Codovilla, deu aos delegados do PSP quando estes lhe presentearam com um exemplar dos Sete Ensaios... de Mariátegui. O secretário do SSAIC desdenhou publicamente o livro, considerando-o uma obra de pouca relevância. Primeiramente, Codovilla objetava ao emprego da forma "ensaio" por considerá-la própria de autores liberais ou conservadores, além de sugerir um trabalho inacabado ou não científico (Galindo, 1994, p. 407-408). A outra objeção dizia respeito ao termo "realidade peruana". Quanto a este último, o comunista argentino fulminou: "realidade peruana, isso não existe." (idem, p. 408)

A tarefa, proposta por Mariátegui de inserir-se no âmbito do movimento comunista internacional e, ao mesmo tempo, manter uma linha política independente - calcada numa apreensão da especificidade peruana e latino-americana - era, sem dúvida, uma tarefa muito difícil, não sendo possível, nos limites deste trabalho, afirmar se haveria então condições para realizá-la ${ }^{(14)}$.

\section{CONCLUSÃO}

Ao longo dos diferentes temas que organizam a polêmica que opôs Mariátegui, tanto a seu ex-aliado Haya de la Torre quanto à IC, percebe-se uma tensão permanente entre a nação peruana e a unidade latino-americana, de um lado, e o socialismo, de outro. As primeiras seriam os projetos políticos de uma intelligentsia radical, da qual Mariátegui e Haya fariam parte, que se lançava contra as velhas estruturas da dominação interna das oligarquias e externa do imperialismo. Já o segundo seria o objetivo último de um corpo teórico — o materialismo histórico — o qual, concebido a partir da Europa, aspirava dar conta de um processo histórico de âmbito universal. Em um extremo, os apristas enfatizavam a nação e o continente em detrimento do socialismo. Já os adeptos do Comintern, no outro extremo, submetiam ambos a este último. Entre estes extremos, José Carlos Mariátegui buscava uma síntese, na medida em que entendia que os universais só se realizam se fossem concretizados sob formas particulares.

Todavia, creio que tal síntese é mais fácil de realizar na teoria do que na prática política, como a própria situação do marxista peruano em seus últimos dois anos de vida deixa claro. Pode-se sustentar, sem dúvida, que a forma organizativa e as diretrizes da IC - organização altamente centralizada e orientada para enquadrar os PCs membros na linha oficial soviética — impediriam, naquele momento, a concretização, no plano

(13) Assim, creio ser supérfluo indagar se Mariátegui foi ou não um leninista. Não era o reconhecimento da autoridade teórica e política de Lênin que o distanciava da IC, mas, sim, sua maneira de empregar o marxismo. Cf. Aricó, 1978, p. XX-XXII.

(14) Após a prematura morte de Mariátegui, o PSP, então sob a liderança de Eudócio Ravinez, mudou de nome para Partido Comunista do Peru, (PCP), passando a submeter-se integralmente às diretrizes da IC. 
político, do encontro entre o nacionalismo e o marxismo. Aqui, retomo a ideia de Eric Hobsbawm, para quem os partidos comunistas deveriam ser entendidos como frutos de um "casamento (...) entre dois parceiros mal-ajustados: uma esquerda nacional e a Revolução de Outubro" (Hobsbawm, 2003, p. 15).

Se seguirmos esse raciocínio, poderíamos concluir que, após a Revolução Cubana, a qual teria promovido a síntese de elementos nacionalistas e socialistas, o projeto intelectual de Mariátegui teria finalmente encontrado vazão (Löwy, op. cit.). Além do marco político representado pelo castrismo e pelo guevarismo, poder-se-ia acrescentar que o marxismo latino-americano se teria constituído, de maneira análoga ao pensamento do próprio Marx, por meio da crítica à "economia política" da CEPAL, resultando nas teorias da dependência (Novais, 1983, p. 25). Esse raciocínio conduziria à conclusão de que Mariátegui, embora não encontrando condições adequadas em seu próprio tempo, teria sido um dos precursores de um marxismo especificamente latino-americano, o qual desabrocharia após 1959.

Aliás, não seria por acaso que a edição de suas obras completas, que teve início nos anos 50 por iniciativa de seus filhos, tenha gerado, nos anos 60 e 70, uma volumosa fortuna crítica, tanto no Peru, quanto na Argentina, França, Itália e mesmo na URSS. Além disso, multiplicaram-se as edições e traduções de Siete Ensayos..., o qual se tornou o livro peruano de não ficção mais lido em todo o mundo ${ }^{(15)}$. O que importa assinalar é que os acontecimentos políticos e novas correntes teóricas que se desdobraram a partir de 1959 - os quais encerraram a hegemonia que os stalinistas haviam mantido sobre o marxismo latino-americano e abriram um novo ciclo revolucionário - teriam criado um contexto favorável ao resgate e difusão da obra mariateguiana.

Todavia, se o contexto posterior à Revolução Cubana criou condições mais favoráveis ao enraizamento do marxismo na América Latina, o problema de fundo que norteou as posições de Mariátegui em sua dupla polêmica - isto é, a necessidade de conciliar o marxismo e a nação - permaneceu em aberto. Como lembra o historiador peruano Alberto Flores Galindo, o marxismo e a nação mantiveram uma relação tensa que, por vezes se transformou em disjuntiva. Se nas revoluções vitoriosas no século XX, como a russa, a chinesa ou a cubana, foi possível encontrar alguma acomodação entre ambos, esses momentos constituíram exceções (Galindo, op. cit., p. 385). Benedict Anderson, em sua obra clássica sobre o tema da nação, sustenta que ao tratar a nação e o nacionalismo como formas "ideológicas" da dominação burguesa, os fundadores do materialismo histórico legaram a seus continuadores um "tabu" que travou por longo tempo a teorização sobre o assunto, crucial para se pensar a política na modernidade (Anderson, 1993).

No caso latino-americano, essa dificuldade do marxismo em abordar o tema da nação pode ser bem ilustrada pelo tema do populismo. Como mencionei na introdução, Löwy considera Haya de la Torre como sendo "populista", no que é acompanhado por outros intérpretes que se inclinam para o marxismo (Löwy, op. cit.). O que me chama a atenção nesses casos é que nunca se discute essa classificação ao empregá-la para se referir ao intelectual peruano, bem como a outras lideranças da esquerda nacionalista latino-americana.

(15) Para a difusão da mais importante obra de Mariátegui, cf. Pericás, no prelo. 
Embora saiba que há nas ciências sociais um amplo e inesgotável debate sobre o conceito de populismo, que ultrapassa o âmbito do marxismo, não posso deixar de advertir, como o faz Ernesto Laclau, que o lugar-comum de toda a interpretação do populismo é começar apontando o caráter "vago e impreciso" da categoria (Laclau, 2004, p. 3). No caso específico dos discípulos de Marx e Engels, o problema está em que políticos e intelectuais como Haya, ao apelar para as noções "ideológicas" de "povo" e "nação", resvalariam para o terreno do "bonapartismo" ou da ideologia "pequeno burguesa", verdadeiros anátemas nesta tradição de pensamento.

O próprio Mariátegui, embora não utilizasse ainda o termo "populismo", ao criticar os apristas, como se viu acima, empregou os mesmos elementos que, mais tarde, seriam incorporados nas teorias sobre o populismo: vagueza e ambigüidade ideológicas, sempre remetidas à "consciência pequeno burguesa" (16). Talvez aí o autor peruano tenha pago um tributo a sua filiação político-intelectual.

Para Juan Carlos Portantiero, o pressuposto marxista de que a sociedade civil predetermina o Estado, teria conduzido os marxistas latino-americanos a não compreenderem o modo pelo qual os "populismos" fundiriam "demandas de classe, de cidadania e de nação" (Portantiero, 1985, p. 58). Creio que a formulação do gramsciano argentino talvez careça de precisão. Para além de uma "visão societária da política", sustento que o problema do marxismo com a política latino-americana, bem como em outras partes do mundo, esteja na pressuposição de um desenrolar universal da luta de classes no qual, em que pese todas as variações locais, ao proletariado sempre estaria reservado o papel fundamental.

Com essas considerações, não quero dizer que Haya estaria certo e Mariátegui errado, ou que o projeto deste, juntamente com o marxismo, deveria ser jogado fora. Quero apenas dizer que, se a tentativa de síntese entre nação e socialismo, perseguida pelo autor dos Siete Ensayos..., pode ser continuada, isso só poderá ser feito seguindo seu exemplo e priorizando a compreensão da realidade, antes que a fidelidade a um sistema teórico.

\section{BiBLIOGRAFIA}

ANDERSON, Benedict. Comunidades Imaginadas. Lisboa: Edições 70, 1993.

ARICÓ, José. "Introducción". In: Idem. (org.). Mariátegui y los Orígenes del Marxismo Latino-Americano. México D. F: Pasado y Presente, 1978.

Marx e A América Latina. Rio de Janeiro: Paz e Terra, 1982.

"O Marxismo Latino-Americano nos Anos da III. Internacional". In: HOBSBAWM, Eric

J. (org.). História do Marxismo. Vol. VIII. Rio de Janeiro: Paz e Terra, 1987.

COX, Carlos Manuel. "Reflexiones Sobre Mariátegui”. In: ARICÓ, José (org.). Mariátegui y los Orígenes del Marxismo Latino-Americano. México D. F: Pasado y Presente, 1978.

(16) Como se pode constatar na sessão anterior, o termo "populismo" no vocabulário do movimento comunista dos anos 20 remetia ao caso russo, dos narodniks. 
DEL PRADO, Jorge. "Mariátegui, Marxista-Leninista Fundador del Partido Comunista del Peru". In. Aricó, José (org.). Mariátegui y los Orígenes del Marxismo Latino-Americano. México d. F.: Pasado y Presente, 1978.

ESCURSIM, Leila. Mariátegui: Vida e Obra. São Paulo: Expressão Popular, 2005.

FALCÓN, Jorge. Anatomie de los Siete Ensayos de Interpretación de la Realidad Peruana. Lima: Amauta, 1985.

FUNES, Patrícia. Salvar La Nación: Intelectuales, Cultura e Política em los Años Viente Latino-Americanos. Buenos Aires: Prometeo Libros, 2006.

GALINDO, Alberto Flores e BURGA, Manuel. Apogeu y Crisis de la República Aristocrática. In: Idem. Obras Completas. Lima: Fundación Andina, 1994.

. La Agonia de Mariátegui: La Polemica com la Comintern. In: Idem. Obras Completas.

Lima: Fundación Andina, 1994.

HALE, Charles. Ideologias Políticas e Sociais na América Latina (1870-1930. In: BETHELL, Leslie (org.). História da América Latina. Vol. V. São Paulo: Edusp, 2001.

HAYA DE LA TORRE, Víctor Raúl. Discurso/Programa. In: Idem. Haya de la Torre o la Política como Missión Civilizadora, Estudo Introdutório e Notas de Jorge Nieto Montesinos. México D. F.: Fondo de Cultura Económica, 2000.

El Aprismo és una Doctrina Completa y um Método de Acción Realista. In: Idem. Haya de la Torre o la Política como Mission Civilizadora. México D. F.: Fondo de Cultura Económica, 2000.

El Estado Anti-imperialista. In: Idem. Haya de la Torre o la Política como Missión Civilizadora. México D. F.: Fondo de Cultura Económica, 2000.

HOBSBAWN, Eric J. Revolucionários: Ensaios Contemporâneos. Rio de Janeiro: Paz e Terra, 2003.

KAYSEL, André. Dois Encontros entre o Marxismo e a América latina. Dissertação de Mestrado: FFLCH-USP, 2010.

LACLAU, Ernesto. The Populist Reason. Londres/Nova Iorque: Verso, 2004.

LÖWY, Michael. O Marxismo na América Latina. São Paulo: Fundação Perseu Abramo, 1999.

MARIÁTEGUI, José Carlos. Aniversário y Balance. In: QUIJANO, Aníbal (org.). Textos Básicos. México D. F.: Fondo de Cultura Económica, 1991a.

Antecedentes y Desarollo de la Acción Clasista en el Peru. In: Idem. Mariátegui Total. Lima: Amauta, 1995a.

. Carta à Céllula Aprista do México. In: QUIJANO, Aníbal (org.). Textos Básicos. México

D. F: Fondo de Cultura Económica, 1991b.

Carta do Grupo de Lima a Célula Aprista do México. In: QUIJANO, Aníbal (org.): Textos Básicos. México D. F., FCE, 1991c.

Carta a Moisés Aroyo Posadas. In: QUIJANO, Aníbal (org.). Textos Básicos. México D.

F: Fondo de Cultura Económica, 1991d.

. El Problema de Las Razas en América Latina. In: QUIJANO, Aníbal (org.). Textos Básicos.

México D. F: Fondo de Cultura Económica, 1991e.

Existe um Pensamiento Hispano-americano?. In: QUIJANO, Aníbal (org.). Textos Básicos. México D. F.: Fondo de Cultura Económica, 1991f.

Punto de Vista Anti-Imperialista. In: QUIJANO, Aníbal (org.). Textos Básicos. México

D. F: Fondo de Cultura Económica, 1991g.

Réplica a Luís Alberto Sánchez. In: Idem. Mariátegui Total. Lima: Amauta. 1995b. 
Siete Ensayos de Interpretación de la Realidad Peruana. Estudo Introdutório e Notas de Aníbal Quijano. Caracas: Bibilioteca Ayacucho, 2008.

MELIS, Antonio. Mariátegui: Primer Marxista de América. In: ARICÓ, José (org.). Mariátegui y los Orígenes del Marxismo Latino-Americano. México D. F: Pasado y Presente, 1978.

MIROXHEVSKY, V. M. El Populismo em El Peru: Contribuición de Mariátegui al Pensamiento Social en América Latina. In: ARICÓ, José (org.). Mariátegui y los Origenes del MMarxismo Latino-Americano. México D. F: Pasado y Presente, 1978.

MONTESINOS, Jorge Nieto. Estudio Introductorio. In: HAYA DE LA TORRE, Víctor Raúl. Haya de la Torre o la Política como Missión Civilizadora. México D. F: Fondo de Cultura Económica, 1978.

NOVAIS, Fernando Antônio. Caio Prado Jr. na Historiografia Brasileira. In: ANTUNES, Ricardo, MORAES, Reginaldo e FERRANTE, Vera (orgs.). Inteligência Brasileira. São Paulo: Brasiliense, 1983.

PERICÁS, Luís Bernardo. Os Sete Ensaios de Interpretação da Realidade Peruana, o APRA e a Internacional Comunista, 2010. No prelo.

PORTANTIERO, Juan Carlos. O 'Nacional-Popular': Gramsci em Chave Latino-Americana. In: COUTINHO, Carlos Nelson e NOGUEIRA, Marco Aurélio (org.). Gramsci e a América Latina. Rio de Janeiro: Paz e Terra, 1985.

QUIJANO, Aníbal. Prólogo e Notas. In: Idem (org.). Textos Básicos. México D. F.: Fondo de Cultura Económica, 1991.

SLESSINGER, Rudolf. Los Comunistas y el Problema Colonial. México D. F.: Pasado y Presente, 1974. THERBORN, Goran. Dialética da Modernidade: A Teoria Crítica e o Legado do Marxismo no Século XX". In: Revista Dados, v. 39, n. 1. Rio de Janeiro: Iuperj, 1995. 